\title{
USING HOT POTATOES PROGRAM FOR READING TEST INSTRUMENT IN ENGLISH TEACHING LEARNING PROCESS
}

\author{
Syamsudin \\ Email: dinsyamsudin13@gmail.com \\ Lusy Kurniawati \\ Email: lusy81sherly@yahoo.co.id \\ Malang Islamic University (UNISMA)
}

\begin{abstract}
In teaching learning process a test is used to examine students' knowledge of something to determine what they know or have learned. Testing measures the level of skill or knowledge that has been reached. Most teachers still used paper based test in giving a test and it is not interactive anymore now. This study will deal with one interactive test items using hot potato program. It is a software program that can give teachers alternative in creating test items. It consists of five test forms; JQuiz, J-Match, J-Cross, J-Cloze, and J-Mix. J-Quiz consists of four basic question types: multiple choice questions, short answer questions, hybrid question and multi select questions. J-Match can give matching questions or ordering exercises. J-Cross can give question in the form of crossword exercises. This can be used for vocabulary test. J-Cloze can perform cloze test items. And the last, J-Mix can perform the mix between J-Quiz and JMatch. This program actually can be applied into four skills; listening, speaking, reading, and writing. Hopefully, this paper only focuses on reading skill. By using hot potatoes in creating material for reading test, the students will feel enjoyable in doing the test. They will have a high spirit in learning English because it is a new challenge and experience for them.
\end{abstract}

Key words: hot potatoes, test, reading

\section{INTRODUCTION}

Hot potatoes is an educational tool for creating quiz games using different applicationswhich are provided. Teachers can create a lot of different quizzes for fun. It has a tremendous educational value of its pedagogical uses for language learning. Hot potatoes is helpful and 
useful for making an interesting education. This program helps the teachers to have better teaching strategies and to improve performance as English teacher. Teachers can use Hot Potatoes application to support their teaching, especially in their instruments for testing the students. This program can also enhance students skills; listening, speaking, reading and writing. On the application of this program, it can be done individually or in form of group. When students have test using this program individually, teacher can measure students' competence individually. But, when it is done by group, it can motivate them working cooperatively. In short, students can enjoy doing assignment.

Hot Potatoes software suite includes five applications that can create exercises for the World Wide Web. The applications are JQuiz, J-Match, J-Cross, J-Cloze, and J-Mix. There is also a sixth application called the Masher that will compile all types Hot Potatoes exercises into one unit. Hot Potatoes is a great tool compatible with HTML and Java script for uploading the work webpage. The different quizzes are compatible with mode making learning more dynamic for students and easy to use for teacher. This paper shows the steps how to create interactive exercises using Hot potatoes that can help the teacher and students in English teaching-learning process and discusses the implementation of this program for education.

\section{HOT POTATOES}

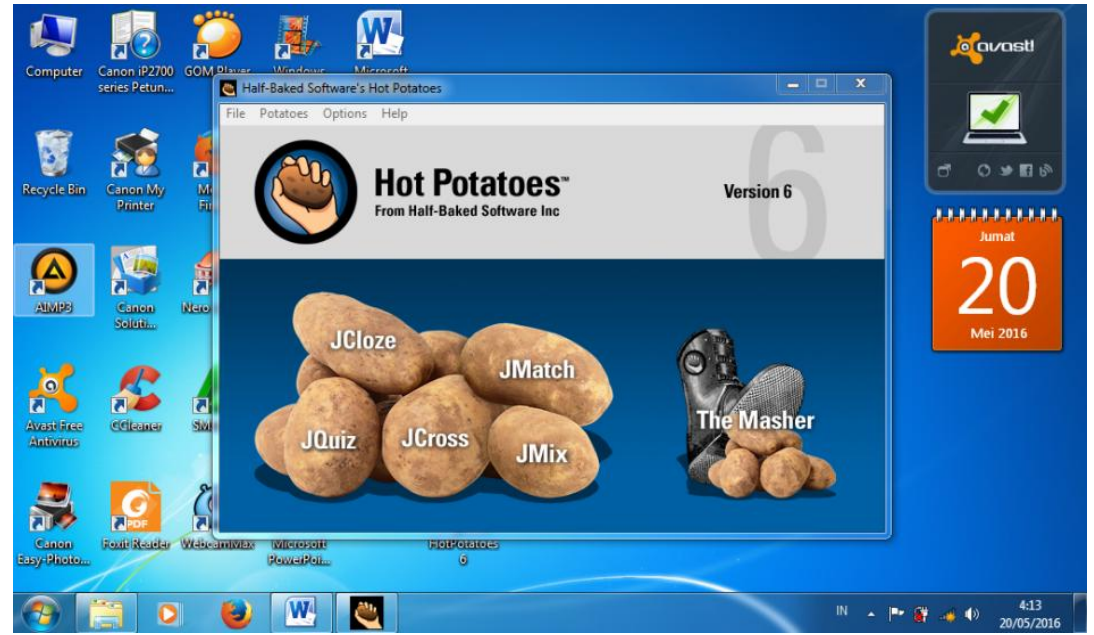


Hot Potatoes is a suite of quiz/drill-authoring software created at the university of Victoria, Canada. It includes five applications, enabling to create interactive exercises:

1. Multiple choice and short answer quizzes (Jquiz)

2. Gap-fill exercises (Jcloze)

3. Matching exercises (Jmatch) has two types: standart and drag-drop 4. Jumbled-sentence or Jumbled-word exercises (Jmix ) has two types : standard and drag-drop

5. Crosswords (Jcross)

This software is free of charge for non-profit educational users who make their exercises available on the web. However, we can download "Hot Potatoes" version 6.0.4, self -extracting, autoinstalling zip file at http://web.uvic.ca/hrd/hotpot/\#downloads. It needs to register the programs before using it by filling in a form on website http://142.104.133.52/admin/registerhtml and then get a registration key from them via email. The user will need to use personal key to unlock all the features of the programs. When the user receives the key, simply start one of the potatoes then click on the Help menu and choose "register". Then the user must enter the user's name and key. The program will create online and offline work. If the program connected to the webpages for the user and the user should know about HTML or Javascript. There are three steps in making an exercise:

1. Entering data (questions, answer, and texts) and save it data file. (Jquiz $=\mathrm{jqz}, \mathrm{Jcloze}=\mathrm{jcl}$, JMatch $=\mathrm{jmt}, \mathrm{JMix}=\mathrm{jmx}$, and Jcross $=\mathrm{jcw}$ )

2. Configurating the output (preparing, the button captions, instructions, and other features of the web)

3. Creating a Web page (compiling exercise into HTML or DHIML page) and save it as a htm file and view the exercise in Web browser.

\section{Creating test instruments using Hot Potatoes Program}

This paper will describe and explain the step how to create the test instruments using some kinds of Hot Potatoes program. The steps in creating the exercises in Hot Potatoes are simple. The user has just to enter the data, configure the output by following all the instructions 
and then compile into HTML pages. After that, he just has to publish it online. It Hot Potatoes, the user can enter exercises like multipleselect question, jumble sentence, gap-fill and short answer. Every answer in Hot Potatoes can now be marked and stored. After the student answered some questions and decided to log out, he/she can back any time and has his score recorded.

There are the following steps in creating test instruments using some kinds of program in Hot Potatoes:

\section{J-Quiz Program}

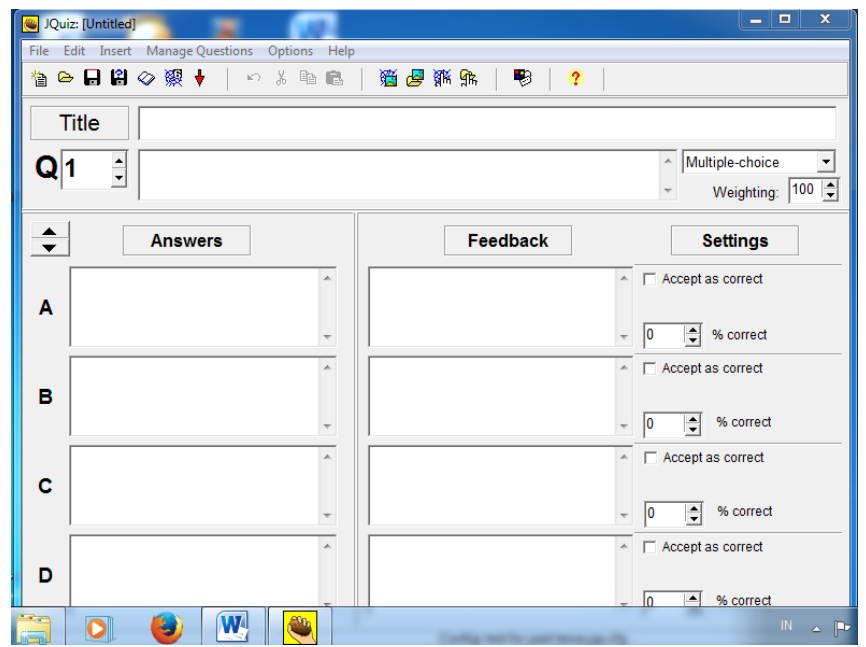

J-Quiz is a tool for creating question-based exercise. Each quiz can consist of an unlimited number of questions with four basic question types: multiple choice questions, ashort answer questions, hybrid question or multi select question. This paper will describe and explain how to create MULTIPLE CHOICE QUIZ. The steps are as follows:

1. Click on the potato labeled Jquiz. A dialogue box will be displayed asking whether Beginner or Advance mode is desired.

2. Click YES to start in Beginner mode

3. In the title box type in the name of the quiz. This function allows the user to give the quiz a name.

4. Select multiple choice in the drop-down menu on the right

5. Begin creating the question, answer and feedback on the right 
a. Type the question in the $\mathrm{Q}(\mathrm{n})$ box (where " $\mathrm{n}$ " is the question number)

b. Type the acceptable answer (multiple Choice) in the A, B, C, and D boxes under the answer column

c. If the user wish to leave feedback, type the desire feedback for each answer in the boxes in the FEEDBACK column

d. Check the box next the multiple choice option that is correct under the setting

6. One all entires have been made, go to file $>$ save and save the quiz. Remember don't put any space in the name

\section{J-Match Program}

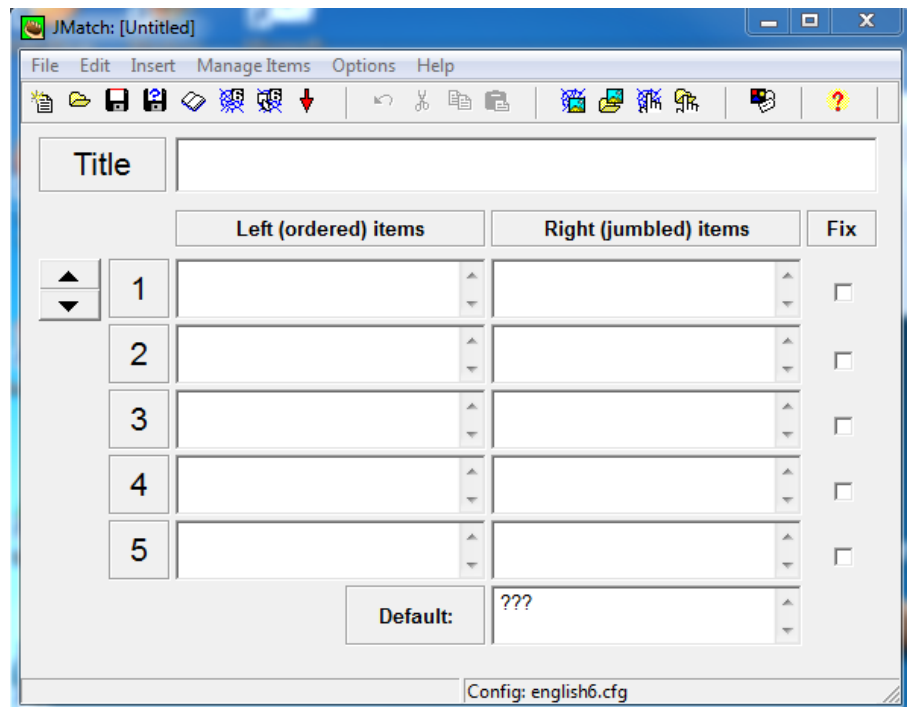

The JMacth program matching or ordering exercises. A list fixed items either pictures or text appears on the left with jumbled items on the right. This can be used for matching voc abulary to pictures or translation, or ordering sentences to form a sequence or a conversation. When the user open Hot Potatoes software, he will see the screen below. Click on the potato marked "JMacth". The user will see a template that looks and operates like the JQuiz template. The same options are acrros the top. The steps are as follows:

1. Click on the JMatch potato

2. Give the exercise title 
3. For each exercise, enter the items in order as above, when the exercise is loaded, the right hand list will be the one that is jumbled

4. Save the (jmt) exercise: the user needs to name it; save it to your desktop for the moment

5. Export the exercise to the web and name the HTML file (no space, no capitals) save this to the user's web site folder.

\section{J-Cross Program (Crosswords)}

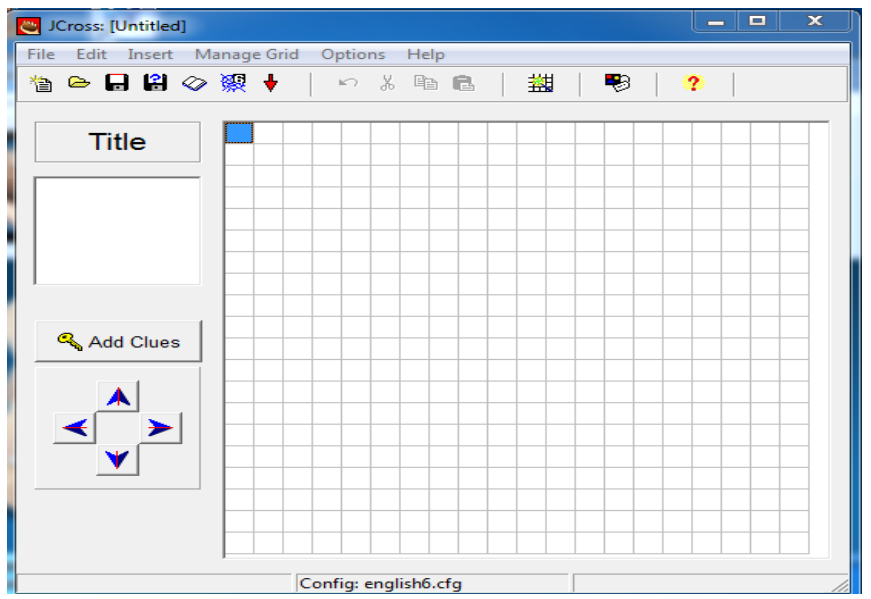

JCRoss is used to make crossword exercises. When the user open Hot Potatoes software, the user will see a pile of potatoes with different words on them on the left. Click on the potato marked "JCross". Here the steps:

1. Across the top and see the word "FILE", "EDIT", "INSERT", "MANAGE GRID”, “OPTION" and"HELP”. Under MANAGE GRID choose "AUTOMATIC"

2. A box will pop up that says "create a crossword grid automatically"

3. The direction tells "enter each word or phrase on a separate line"

4. Type in the following words : kirk, luc, latonge, kira, troi, home, katnyn,spock, cocher, mccoy.

5. Click on the box that say "make the grid"

6. The grid on the left side hand side, find the word "tittle". There should be on empty box undreneath it. In the empty "TITTLE" box, type "star trek" 
7. Click on the box that says

"ADD CLUES". This part gets tricky. There is a GREEN "ok" button on the screen. This button is needed when finished entering the clue, than ignore it

8. Two boxes appear after click on "ADD CLUES". The top box is labeled "ACROSS" the bottom box is labeled "DOWN". Start will either box. Click a word to highlight it. The cursor will flash in the box below. Click on the word "maccoy". It will be highlight in gray, type "original" "star trek" "doctor" in the clue box

9. Fihished inserting the clue, click on the Red "ok" button on the right

10. Insert another clue. Select and highlight another word, type next clue

11. After finishing entering all clues, click on the Green "ok"

12. Under "option", choose CONFIGURE OUTPUT"

13. Under "file" choose "SAVE AS" and save exercise. Remember just one word such as "star", "star_trek"

\section{J-Cloze program}

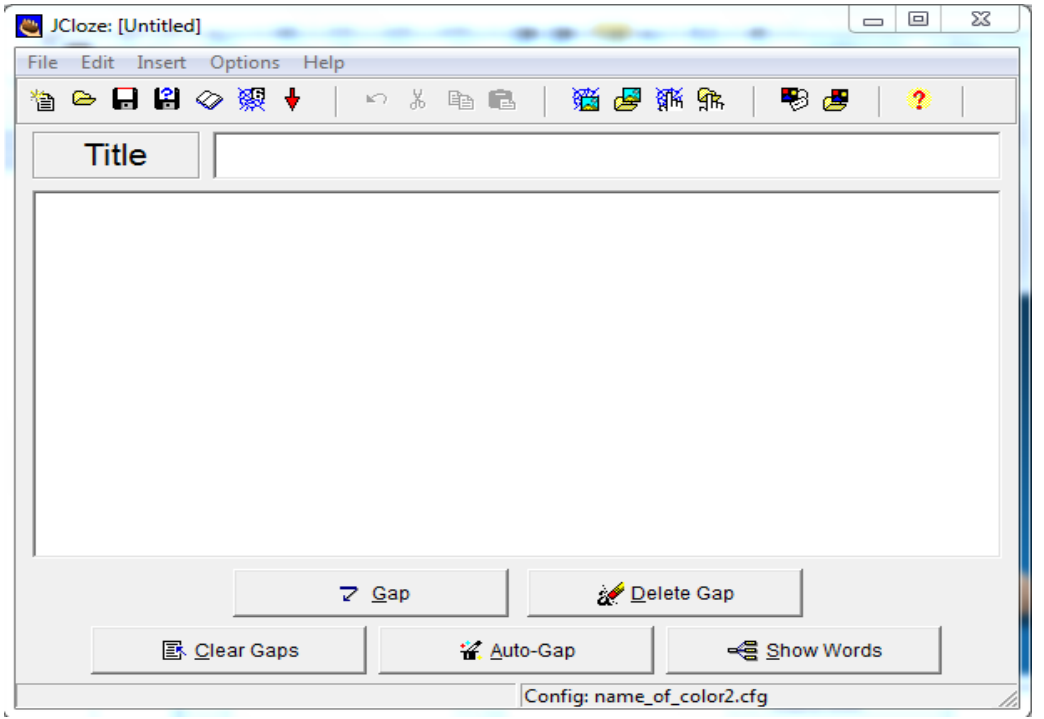

This quiz creates a fill type gaps exercise. The steps are:

1. In the title bar type the name of quiz 
2. In the dialogue box underneath type in the paragraph wish the quiz to be made on (you have copied this text from anywhere and paste it in here)

3. To create gap word, select the word and click on the gap button. This will give dialogue box with the options of adding a clue or alternative correct answer

4. Gapped words remain in red on this screen but will appear on web page

\section{THE PRINCIPLE OF TEACHING READING}

Nation $(2009$, p. 6) states in his book titled Teaching ESL/EFL Reading and Writing that there are some principles for teaching reading;

1. Meaning-focused input

a. Practice and training in reading should be done for a range of reading purpose.

b. Leanres should be doing reading that is appropriate to their language proficiency level.

c. Reading should be used as a way of developing language proficiency.

2. Meaning-focused output: reading should be related to other language skills

3. Language-focused learning

a. Learners should be helped to develop the skills and knowledge needed for effective reading.

b. Learners should be given training and practice in a range of reading strategies.

c. Learners should be given training and practice in integrating a range of strategies.

d. Learners should become familiar with a range of text structures.

4. Fluency development

a. Learners should be helped and pushed to develop fluency in reading.

b. Learners should enjoy reading and feel motivated to read

c. Leaners should read a lot. 
While Brown and Lee (2015, p. 409) state that some principles should be notice in teaching reading skills;

1. In an integrated course, include a focus on reading skills

2. Offer reading on relevant, interesting, motivating topics

3. Balance authenticity and readability in choosing texts. Here, Nuttal (1996) offered there are three criteria for choosing reading texts for students;
a. Suitability of the content
b. Exploitability of the content
c. Readability of the text

4. Encourage the development of reading strategies

5. Include both bottom-up and top-down technique

6. Follow the "SQ3R" sequence (Survey, Question, Read, Recite, Review)

7. Design pre-reading, while-reading, and post-reading phase.

8. Build ongoing (informal) assessment into technique.

\section{THE PRINCIPLE OF READING TEST OR ASSESSMENT}

A test is a method of measuring a person's ability or knowledge in a given domain, with an emphasis on the concept of method and measuring. While assessment is an ongoing process that encompasses a much wider domain (Brown and Lee, 2015, p. 498). Further they explain that there are some items in the principle of language assessment;

1. Practically. It means it can be meant of financial limitation, time constraints, ease of administration, and scoring and interpretation.

2. Reliability. It means the test is consistent and dependable.

3. Validity. It should covers content validity, face validity and construct validity.

4. Authenticity. It means a concept taht is little slipppery to define within the art and the science of evaluation and designing tests.

5. Washback. It includes the effects of an assesment on teaching and learning prior to the assesment itself.

Table 1. Principles of assesment

\begin{tabular}{|l|l|l|}
\hline No & Princeple & Associated concept \\
\hline 1. & Practically & Clear administration detail \\
\hline
\end{tabular}




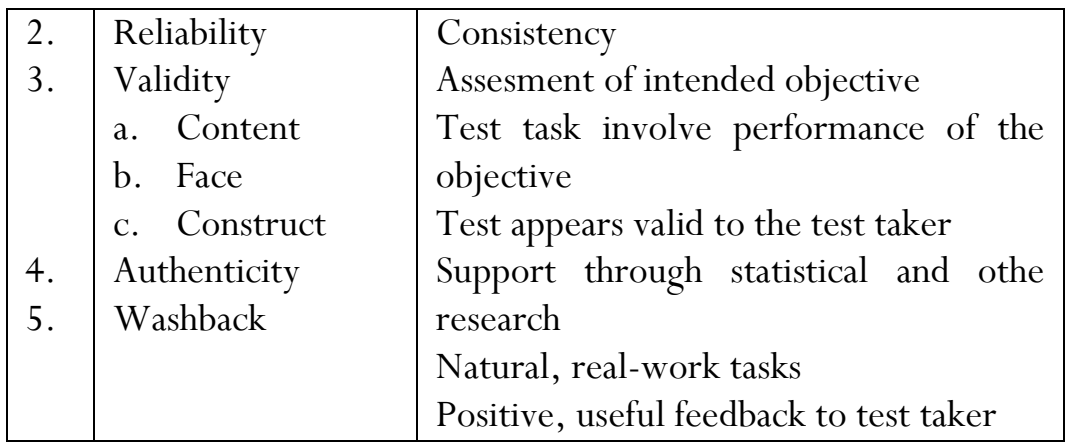

On the other hand, Nation (2009, p. 75) gives explanation there are several reasons for assesing reading and the skills and knowledge that are involved in reading. They include assessing to encourage learning, assessing to monitor progress and provide feedback, assessing diagnose problems and assessing to measure proficiency.

It can be explained in type of assessment;

1. Motivating or Encourage Learning. It can be the form of Speed Reading Graphs, Reading Logs, and Oral Book Reports.

2. Measuring Achievement. It can be the form of Pronominal Question or Imperative, True/False, Yes/No, Alternative Question and Multiple choice.

3. Diagnosing Problem. It can be the form of Reading aloud, Vocabulary Test, True/False Vocabulary Test, Tests of Grammatical Knowledge, Testing Reading Speed, or Other cases.

4. Measuring Reading Proficiency. It can be the form of Cloze Test and Selective Cloze.

Table 2. Goals, Purposes and Means of Reading Assessment

\begin{tabular}{|l|l|l|l|}
\hline No & $\begin{array}{l}\text { Goals of } \\
\text { assessment }\end{array}$ & Purpose & Ways of assessing \\
\hline 1 & Motivate & $\begin{array}{l}\text { Encourage } \\
\text { learning }\end{array}$ & $\begin{array}{l}\text { Reading logs } \\
\text { Book reports } \\
\text { Comprehension tests } \\
\text { Speed reading graphs }\end{array}$ \\
\hline 2 & $\begin{array}{l}\text { Measure } \\
\text { achievement }\end{array}$ & $\begin{array}{l}\text { Monitor progress } \\
\text { Guide teaching }\end{array}$ & $\begin{array}{l}\text { Comprehension tests } \\
\text { Speed reading graphs }\end{array}$ \\
\hline
\end{tabular}




\begin{tabular}{|l|l|l|l|}
\hline & & $\begin{array}{l}\text { Provide feedback } \\
\text { to the learner } \\
\text { Award a grade }\end{array}$ & \\
\hline 3 & $\begin{array}{l}\text { Diagnose } \\
\text { problems }\end{array}$ & $\begin{array}{l}\text { Isolate reading } \\
\text { difficulties } \\
\text { Provide focused } \\
\text { help }\end{array}$ & $\begin{array}{l}\text { Reading aloud } \\
\text { Vocabulary tests } \\
\text { Receptive grammar } \\
\text { test } \\
\text { Translation } \\
\text { Speed reading test }\end{array}$ \\
\hline 4 & $\begin{array}{l}\text { Measure } \\
\text { proficiency }\end{array}$ & $\begin{array}{l}\text { Award a grade } \\
\text { See if standards } \\
\text { are achieved }\end{array}$ & $\begin{array}{l}\text { Comprehension tests } \\
\text { Cloze test } \\
\text { Speed reading tests }\end{array}$ \\
\hline
\end{tabular}

\section{THE IMPLEMENTATION HOT POTATOES IN TEACHING LEARNING PROCESS}

In teaching learning process, teachers should prepare everything dealing with it. It could be curriculum, syllabus, lesson plan, technique, textbook, material, and assessment for the students. They must not neglect them. Those items are condition to achieve the goal of the education stated on the curriculum. But the writer would not explain all the aspects, he only takes some that most related to the tittle above, those are; lesson plan, technique, textbook and material, and assessment.

\section{Lesson Plan}

Lesson plan is a set of plan for the teachers before they act as the role model in the classroom. It is the most important part for the teacher because lesson plan covers all aspect that is going to be achieved in teaching learning process. There are some aspects that should be considered in constructing lesson plan. Brown (2015, p. 198) states the aspects of lesson plans should cover;

1. Goal. It mostly states about the big purposes about the students. It is sometimes not explicitly stated, but rather than is implied.

2. Objectives. It states about the short purposes about the students. There are terminal objectives and enabling objectives.

3. Material and Equipment. A good planning knowing what you need to take with you or to arrange to have in your classroom. 
4. Procedures. Set of plan should have; opening, set of activities and closing.

5. Assessment. This is the instrument to measure what has been covered or achieved by our students

6. Extra-class work. This activities can be done by student beyond the class hour. It can be done in group or individually

\section{Technique, Textbooks and Material.}

Technique, textbook and material are going to be used in teaching learning process must be in line to lesson plan. Those are the superordinate term to various activities that teacher or students perform in classroom. Teachers should be creative in defining technique, textbook and material. It is needed to avoid monotony in classroom.

\section{Assessment}

Assessment is a part of plans that covers instrument to measure students' achievement in teaching learning process. The result of the test or assessment is the most important thing to determine whether their teaching strategies effective or not. Then they can consider what they should do to their students. They can reconstruct their strategy, approach, methodology or even their material if their students' achievement is beyond their expectation.

Most teacher in doing their assessment or test for their students are still using traditional way. They give the paper test for their students and students do this test, last they submit their work. This method is monotonous and boring for the students. Hot Potatoes give the alternative way in constructing the assessment or test for the students. This program is beneficial for not only teachers but also students.

Teachers can create the form of assignment as they wish. It can be true/false, cloze test, matching word or sentence, and in the form cross word to enlarge students' vocabularies. These various forms can also encourage students to do the tests or assignments because they will feel another way in doing their work. Moreover, Hot Potatoes offer an interactive test. Students can check directly whether their 
work is correct or wrong, also, they can get result of their work. Even, students can check the correct answer if their works are not correct. By using this program, teachers will have effective time to have their students test and explain the correct answers of the tests.

\section{CONCLUSION}

In summary, Hot Potatoes is a great freeware program for language teachers to create offline or upload exercises on their personal websites. Creating exercises for learner gives them space to repeatedly practice the target language. All in all, Hot Potatoes, with its variety of straight forward and descriptive features are very useful for teacher and everyone who interested in making interactive exercises for different purposes.

This program can give the alternative way in giving tests or assignment to the students. Students accustomed to be given test in form of paper test will feel another way in doing tests using Hot Potatoes. This test can not only give written form of test items but also but also give test which inserts music or voice and picture or image. It will be interesting for the students and they will not feel stressful in doing the test items.

In short, this program is suitable choice for language learning instructors who want to make interactive activities. This program can help teacher to create exercises or test items for the students.

\section{REFERENCES}

Brown, H. Douglas \& Lee, Heekyeong. (2015). Teaching by Principle: An Interactive Approach to Language Pedagogy. New York: Pearson Education, Inc.

Mistar, Junaidi. (2010). Pedoman Penulisan Tesis: Program Pascasarjana Univeristas Malang. Malang: PPs Unisma Press.

Mistar, Junaidi. (2016). Assessment in the 2013 English Curriculum. Presented on Seminar dan Worksohp Nasional: Pembelajaran dan Assessment Bahasa Inggris Berdasarkan Kurikulum 2016 held by Graduate Program Unisma, Malang, 19 Mei 2016.

Nation, I.S.P. (2009).Teaching ESL/EFL Reading and Writing. New York: Routledge Publisher 